\title{
White Bread Fortified with Calcium from Eggshell Powder
}

\author{
NICOLETA PLATON ${ }^{1}$, VASILICA-ALISA ARUS ${ }^{*}$, ANA-MARIA GEORGESCU ${ }^{1}$, \\ ILEANA DENISA NISTOR ${ }^{1}$, NARCIS BARSAN ${ }^{2}$ \\ 1" Vasile Alecsandri" University of Bacau, Faculty of Engineering, Catalysis and Microporous Materials Laboratory, \\ Department of Chemical and Food Engineering, 157 Marasesti Str., 600115, Bacau, Romania \\ 2"Vasile Alecsandri" University of Bacau, Faculty of Engineering, Department of Environmental Engineering and \\ Mechanical Engineering, 157 Marasesti Str., 600115, Bacau, Romania
}

\begin{abstract}
This paper presents the preparation of white bread with different hen eggshell powder additions. The aim of this paper is to resolve at least two important aspects: the waste recovery from food industry and fortification of white bread with minerals (calcium). The addition of eggshell powder to the white bread preparation was up to $2 \%$ and an increase in bread quality was on elasticity and humidity starting with $0.5 \%$ eggshell powder addition. Bread aging occurred 10 to $12 \mathrm{~h}$ after its baking. After $24 \mathrm{~h}$, all physico-chemical properties of bread crust and crumb in the case of fortified bread with calcium had a positive effect.
\end{abstract}

Keywords: white bread, eggshell powder, waste recovery, natural additive

\section{Introduction}

Next generation products and processes are guided by sustainable ecology, eco-efficiency and green chemistry [1]. Current scientific researches from food industry, biotechnologies, green chemistry are focused on using of unconventional materials for obtaining functional foods, bioactive compounds, food ingredients, etc. [2-7].

Due to a high consumption of hen eggs, a large amount of egg waste is discarded, some studies being focused on eggshell-derived components as a renewable resource. This massive amount of waste could potentially be used in different applications by offering great material for industrial and structural applications. Eggshell is a natural bio-ceramic composite, with a combination of both inorganic and organic components that have exceptional characteristics. The unique chemical composition and substantial availability make eggshells a potential source for bio-based calcium carbonate [8].

The egg (Figure 1) consists of a protective layer, i.e., eggshell (ES), two membranes associated with ES (ESM), an egg white and yolk. Egg is very important in human nutrition due to protein and nutrients present in liquid state as egg white and yolk. The solid protective layer (ES) and its associated membranes (ESM) are considered waste [9].

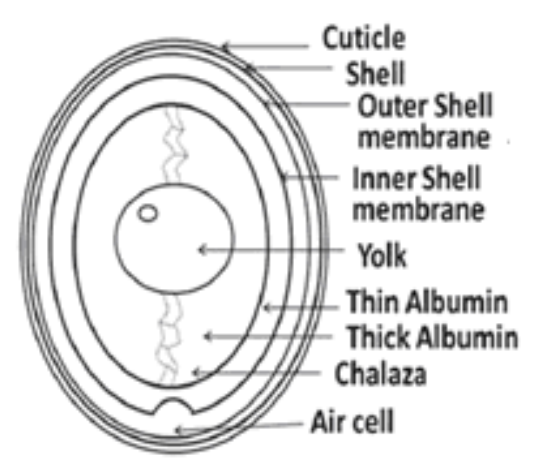

Figure 1. Structure of egg [9]

\footnotetext{
*email: arusalisa@yahoo.com
} 
The protective layer consists of the outer layer (cuticle), below the cuticle is the layer of calcium carbonate (testa) and finally the inner layer (mammillary layer) [9]. Main components of the protective layer are carbonates, phosphates and sulphates of calcium and magnesium and organic matter, the percentage of calcium carbonate being of about 90\% [9]. In Traces of $\mathrm{Na}, \mathrm{K}, \mathrm{Mn}, \mathrm{Fe}, \mathrm{Cu}$, and $\mathrm{Sr}$ metals are also present in the protective layer. ESM have cca. 60\% proteins, i.e., collagen (35\%), glucosamine $(10 \%)$, chondroitin $(9 \%)$ and hyaluronic acid $(5 \%)$, and small amounts of inorganic components e.g. $\mathrm{Ca}, \mathrm{Mg}, \mathrm{Si}, \mathrm{Zn}$ [9]. Study of ES structure has been a fascinating area of research in the recent years [10].

The nutritional value of wheat flour, excepting the initial quality of wheat, is determined by the degree of extraction that substantially alters the content of vitamins and mineral salts. Nowadays, due to the grinding process and the environmental conditions, at industrial level, flour or white bread enrichment has been made with various minerals, vitamins, enzymes, etc. The amounts of vitamins and mineral salts added to the flour for enrichment vary from country to country, starting from $0-1110 \mathrm{mg}$ $\mathrm{Ca} / 453 \mathrm{~g}$ flour $\left(\mathrm{Ca}\right.$ as $\left.\mathrm{Ca}_{3}\left(\mathrm{PO}_{4}\right)_{2}, \mathrm{CaCO}_{3}, \mathrm{CaHPO}_{4} \times 2 \mathrm{H}_{2} \mathrm{O}, \mathrm{CaSO}_{4}\right)$ [11]. From the nutritional point of view, $1000 \mathrm{mg}$ of $\mathrm{Ca}$ for adults and $1200 \mathrm{mg}$ for pregnant and young people are daily recommended, while for women aged over 45 years, a daily intake of $1500 \mathrm{mg}$ of $\mathrm{Ca}$ is recommended. The amount of $\mathrm{Ca}$ can be supplemented in the case of people suffering from hypertension, cardiovascular disease, osteoporosis and dyslipidaemia [12].

According to the data reported in the literature, the content of $\mathrm{Ca}$ in ES is 70-95\%. Higher values are in the crust of the raw egg and low values in the shell subjected to heat treatment. In a mass of $0.457 \mathrm{~g}$ of $\mathrm{ES}$ is found about $0.320 \mathrm{~g}$ of $\mathrm{Ca}$ [11]. ES is probably the best natural source of $\mathrm{Ca}$ and it is easily digested and absorbed.

Growing interest is now focused to ES powder because it can be used as a mineral source for fortification of different food products, e.g., yoghurt [13], biscuits [14], chocolate cakes [15], bread [16-18]. Based on this information, this study contributes to the valorisation of food waste (ES) to obtain a new product: white bread enriched in $\mathrm{Ca}$ as a natural source. The white bread was chosen as application from two points of view: it is a basic food of population all over the world and its minerals content is lower than that of bread obtained from integral wheat flour.

By using the natural materials, is wanted to achieve the following aspects: the shelf life of a product to be as long as possible and also the negative effects of additives to be eliminated in the same time. Using ES as additive, the foods can be fortified with mineral substances. Also is known that soils are poor in minerals and grains default. Through the large amounts of $\mathrm{Ca}$ and $\mathrm{Mg}$ in ES and then in bread, a fortification with minerals of white bread is aimed.

The novelty and the originality of this paper is the using of hen ES powder at bread fabrication in order to obtain bread with higher nutritive properties than those of bread currently available on the market.

\section{Materials and Methods}

\subsection{Raw materials}

The raw materials used for fortification of white bread with Ca from ES powder were: white wheat flour 650 type, yeast, water, salt and ES from the waste of our household.

To obtain ES powder, it was necessary to wash the ESs for many times. The membranes were separated and finally the ESs were dried into an oven at $50^{\circ} \mathrm{C}$ for $10 \mathrm{~min}$ to avoid any further contamination. The dried ESs were grounded, followed by pulverization process to obtain particles size of about $125 \mu \mathrm{m}$ (similar with flour particles size). Drying temperature may lead to a decreasing in the amount of $\mathrm{Ca}$ from ES powder according to the experiments published in the literature $[18,19]$.

\subsection{Bread obtaining}

The bread was prepared by using a bread machine having the first kneading time of 10 min (first fermentation $10 \mathrm{~min}$ ), the second kneading time of $10 \mathrm{~min}$ (second fermentation $35 \mathrm{~min}$ ) and baking 
process of 65 minutes. The recipe is presented in Table 1.

Table 1. Recipe for bread with ES powder addition

\begin{tabular}{c|c|c}
\hline Raw materials & $\begin{array}{c}\text { Amount } \\
(\mathbf{g})\end{array}$ & $\begin{array}{c}\text { Temperature } \\
\left({ }^{\mathbf{C}} \mathbf{C}\right)\end{array}$ \\
\hline White wheat flour, 650 type & 350 & 20 \\
\hline Water & 210 & 32 \\
\hline Salt & 5.25 & 20 \\
\hline Yeast & 10.5 & 20 \\
\hline ES powder addition $(\%)$ & $0,0.5,1.0,1.5,2.0$ & 20 \\
\hline
\end{tabular}

\subsection{Quality evaluation of bread}

Quality evaluation of bread was realized according to the data presented in Table 2.

Table 2. Quality evaluation of bread with ES powder addition

\begin{tabular}{c|c|c}
\hline \multirow{2}{*}{ Physico-chemical properties } & Humidity & STAS 91/1960 \\
\cline { 2 - 3 } & Ash & STAS 90/1988 \\
\cline { 2 - 3 } & Acidity & STAS 91/1983 \\
\cline { 2 - 3 } & Porosity & STAS 91/1983 \\
\cline { 2 - 3 } Sensorial properties & Elasticity & \multirow{2}{*}{ STAS 91/1983 } \\
\hline & $\begin{array}{c}\text { Shape, external appearance, volume } \\
\text { Appearance of bread crust } \\
\text { Appearance of bread crumb } \\
\text { Consistency and behavior in mastication } \\
\text { Bread smell } \\
\text { Bread taste }\end{array}$ & \\
\hline
\end{tabular}

\section{Results and discussions}

The percentage of ES powder added to the bread preparation was up to $2 \%$ and an increase in bread quality was observed especially on elasticity and humidity starting with $0.5 \%$ ES powder addition. Bread aging, which involved essential changes in bread quality, occurred after 10 to $12 \mathrm{~h}$ and increased with the duration of storage. After $24 \mathrm{~h}$, all physico-chemical properties of bread crust and crumb in the case of fortified bread with $\mathrm{Ca}$ had a positive effect (Table 3, Figures 2-4). This shows that the ES powder plays a preservative role through the freshness of the bread obtained. These ESs can therefore be called natural additives used to increase the preserving and $\mathrm{Ca}$ supplements for bread fortification as a nutritional supplement.

Table 3. Physico-chemical properties of bread with ES powder addition

\begin{tabular}{c|c|c|c|c|c|c}
\hline No. & $\begin{array}{c}\text { Physico-chemical } \\
\text { properties }\end{array}$ & $\begin{array}{c}\text { Sample 1 } \\
(\mathbf{0 \%})\end{array}$ & $\begin{array}{c}\text { Sample 2 } \\
\mathbf{( 0 . 5 \% )}\end{array}$ & $\begin{array}{c}\text { Sample 3 } \\
(\mathbf{1 \%})\end{array}$ & $\begin{array}{c}\text { Sample 4 } \\
(\mathbf{1 . 5 \%})\end{array}$ & $\begin{array}{c}\text { Sample 5 } \\
(\mathbf{2 \%})\end{array}$ \\
\hline 1. & Mass (g) & 471 & 479 & 493 & 501 & 511 \\
\hline 2. & Elasticity (\%) & 83 & 91.66 & 94 & 92.3 & 90 \\
\hline 3. & Porosity (\% vol.) & 94 & 94 & 92 & 92 & 92 \\
\hline 4. & Moisture (\%) & 35.54 & 35,6 & 37.81 & 39 & 40.08 \\
\hline 5. & Ash (\%) & 0.08 & 0.11 & 0.17 & 0.25 & 0.29 \\
\hline 6. & Acidity $\left({ }^{\circ} \mathrm{A}\right)$ & 0.8 & 0.6 & 0.6 & 0.6 & 0.6 \\
\hline
\end{tabular}




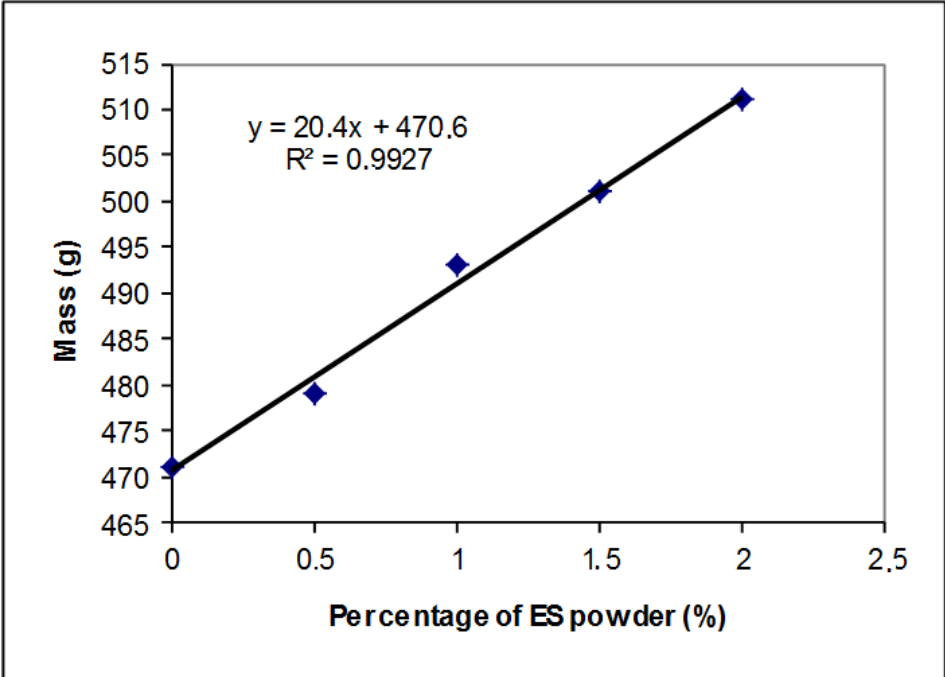

Figure 2. Influence of ES powder addition on bread mass

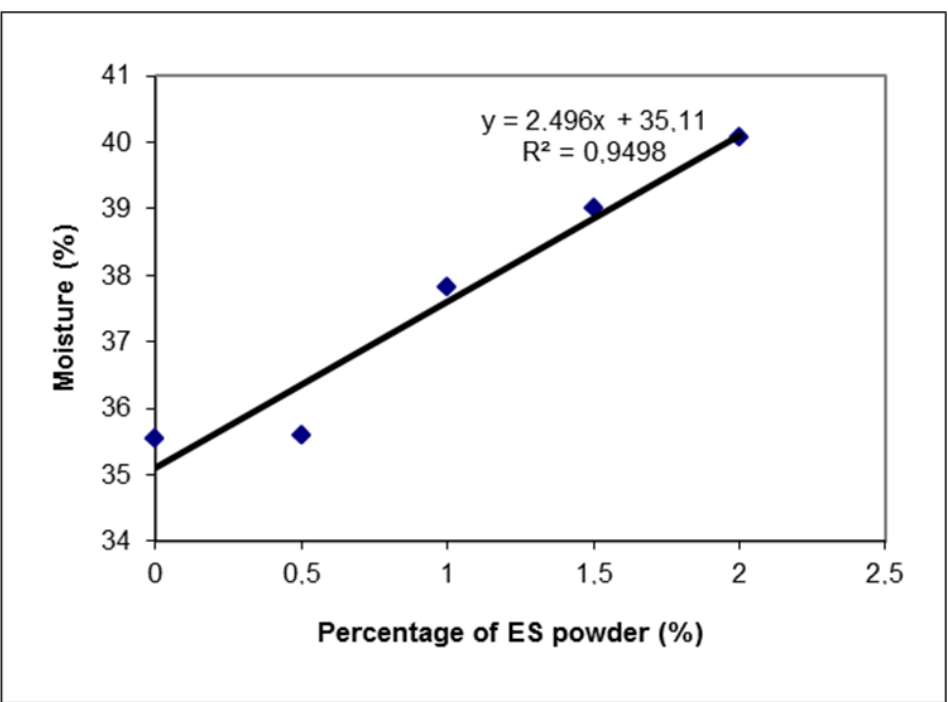

Figure 3. Influence of ES powder addition on bread moisture

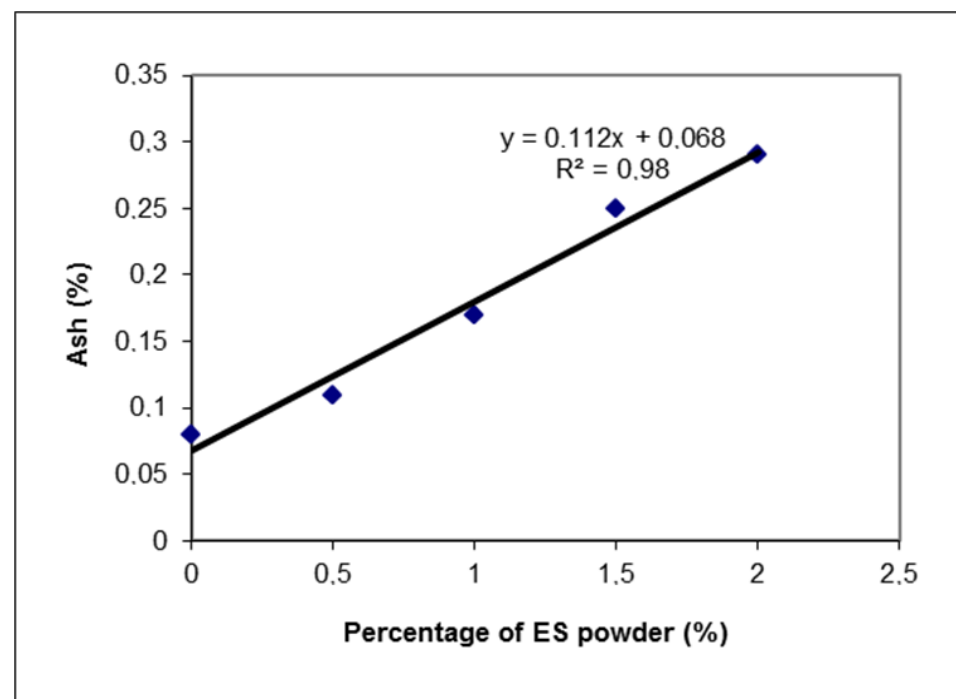

Figure 4. Influence of ES powder addition on bread ash 
The obtained bread was also sensory analyzed (Table 4) with a scoring scale of maximum 20 points for the evaluation of organoleptic characteristics [19]. The maximum total score was 19/20.

Table 4. Sensorial analysis of bread with ES powder addition

\begin{tabular}{c|c|c|c|c|c}
\hline \multirow{2}{*}{ Sensorial characteristics } & \multicolumn{5}{|c}{ Samples } \\
\cline { 2 - 6 } & $\begin{array}{c}\text { Sample 1 } \\
(\mathbf{0 \%})\end{array}$ & $\begin{array}{c}\text { Sample 2 } \\
(\mathbf{0 . 5 \% )}\end{array}$ & $\begin{array}{c}\text { Sample 3 } \\
(\mathbf{1 \% )}\end{array}$ & $\begin{array}{c}\text { Sample 4 } \\
(\mathbf{1 . 5 \%})\end{array}$ & $\begin{array}{c}\text { Sample 5 } \\
(\mathbf{2 \% )})\end{array}$ \\
\hline Shape, external appearance, volume & 3 & 3 & 3 & 3 & 3 \\
\hline Appearance of bread crust & 2.5 & 2.5 & 3 & 3 & 3 \\
\hline Appearance of bread crumb & 3.5 & 4 & 4 & 4 & 4 \\
\hline Consistency and behavior in mastication & 3 & 2 & 2 & 2 & 2 \\
\hline Bread smell & 2.5 & 3 & 3 & 3 & 2.5 \\
\hline Bread taste & 2.5 & 3 & 4 & 4 & 3 \\
\hline Total & $\mathbf{1 7}$ & $\mathbf{1 7 . 5}$ & $\mathbf{1 9}$ & $\mathbf{1 9}$ & $\mathbf{1 7 . 5}$ \\
\hline
\end{tabular}

The addition of ES powder improves the aging and flavor qualities, but the bread has a chew inconvenience, a screech.

The differences in volume and crumb structure for various percentages of ES powder are shown in Figure 5.

The bread has toasted brown crust - golden, slightly crispy. Bread with added ES powder is well cooked, presents elastic crumb, has uniform colour and the knife blade stays clean.

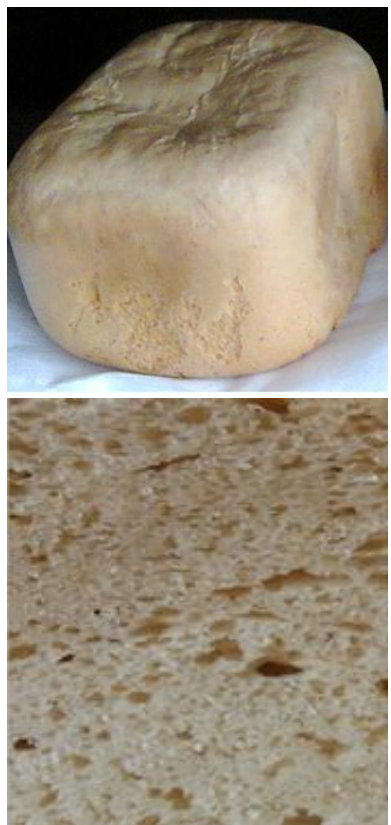

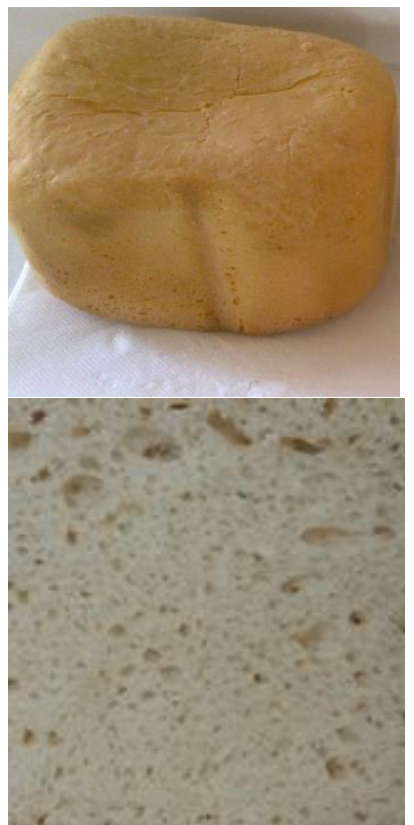

b

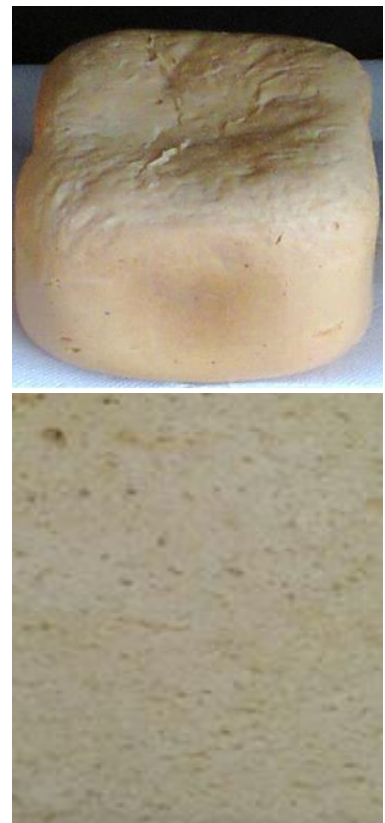

C

Figure 5. Images of $\mathrm{Ca}$ fortified bread with different additions of ES a) $0 \%$; b) $0.5 \%$; c) $1 \%$ 

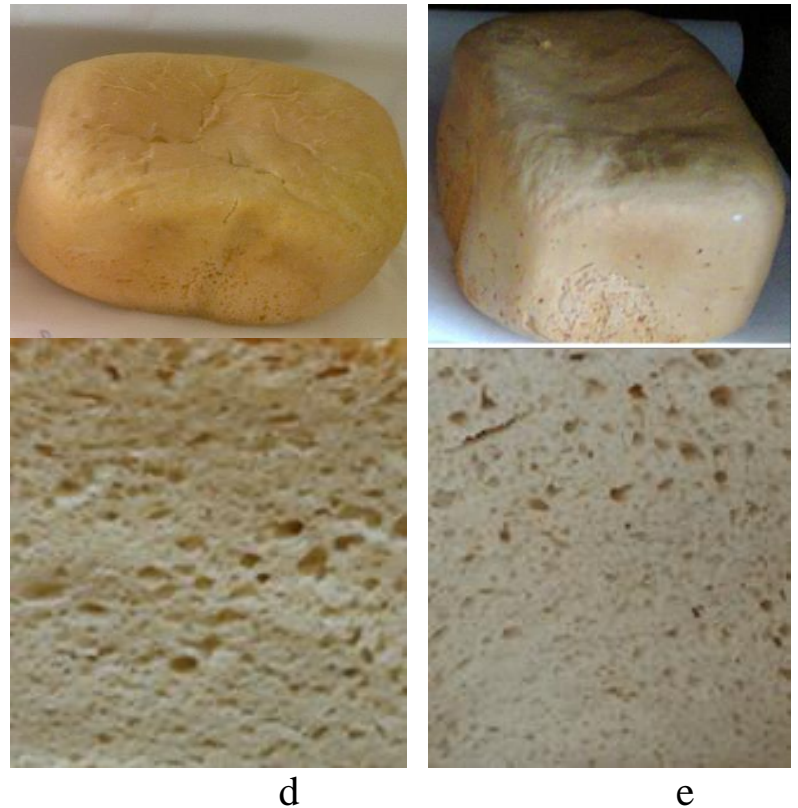

Figure 5. Images of $\mathrm{Ca}$ fortified bread with different additions of ES d) $1.5 \%$; e) $2 \%$

The crumb bread consists of pores, with walls formed during the baking process from compact coagulated gluten mass, partially swollen and gelatinized starch granules being found inside the pores' walls. In fresh bread, the gelatinized starch granules are in contact with the mass of coagulated proteins throughout their surface, with no visible delimitation between them. In aged bread, partially gelled starch granules are visibly separated from each other, due to the fact that a thin layer of air forms around their surfaces, as the volume of the starch granules is reduced and the proteins on the pore walls does not undergo any change [19]. ESs having adsorption properties absorb this air and thus can be explained the effect of increasing bread consistency in which ESs are added, respectively, the breaking of the bread is prevented.

Is is considered the process of demolding starch as a cause of bread aging [19]. During the baking process, the starch absorbs the water released by the coagulating, swelling, partially gelled proteins, passing from the initial crystalline state in an amorphous state [19]. In our study, it is possible to explain the increase in bread consistency, through the water released during the baking process, that will be absorbed by the ES powder too, and after the baking process, this amount of water can be gradually released.

During bread aging time, water diffuses from gluten to starch, contributing to the reorganization of macromolecules of amylose and amylopectin as well as their transition from amorphous state to crystalline state. In fresh crumb free water represents $75 \%$, in which a number of substances are solubilized forming the aqueous phase between starch and gluten [19].

In our study, we could explain the aging process by the addition of ES powder. The ES powder is interposed by the water adsorbed between starch and gluten either in the baking process or after the bread baking. In the aged crumb of bread without ES, the water drops to half, causing the concentrating of aqueous phase and decreasing of elasticity. In our research an increasing in elasticity can be observed, so we could say that the aging process with the characteristic consequences is delayed.

\section{Conclusions}

In food industry from Romania, the bakery industry occupies an important place in the production of consumer goods, bread being a staple food in the regular daily diet because the body provides some important substances that are necessary for vital activity. 
The using of ES in bakery industry brings several advantages: waste recycling in food industry, nutritionally enriching with $\mathrm{Ca}$, increasing of bread preserving. The nutritional value of bread is an important element to the daily ration of food and the subject of wide research in the field of nutrition. This value is conferred not only by energy intake (calories), based on their increased groove-sugars (carbohydrates), proteins and lipids (fats), but also by the contribution of all components in those products, that are easily assimilated by the human body.

The final product obtained has pleasant taste and smell, but also better developed and the interaction of $\mathrm{Ca}$ from ES powder determines the freshness of bread.

Acknowledgments: This work was funded by the Ministry of Education and Research, through the National Council for the Financing of Higher Education, Romania, grant number CNFIS-FDI-20200461.

\section{References}

1. JYOTHI, M.S., YADAV, S., BALAKRISHNA, G., Effective recovery of acids from egg waste incorporated PSf membranes: A step towards sustainable development panel, Journal of Membrane Science, 549, 2018, 227-235.

2. JINESCU, C., ARUŞ, V.A., PÂRVULESCU, O.C., NISTOR, I.D., Modelling of batch lactic acid fermentation in the presence of anionic clay, Food Technology and Biotechnology (FTB), 52 (4), 2014, 448-458.

3. ARUŞ, V.A., PÎRVULESCU, O.C., JINESCU, C., NISTOR, I.D., Mathematical modeling of the retention process of lactic acid on anionic clay particles using mechanical mixing for process intensification, Rev. Chim., 62(12), 2011, 1180-1184.

4. POIANA, M.-A., GERGEN, I., RADU, F., ALEXA, E., RIVIȘ, A., Modificările diferitelor forme de fosfor din pâine prin adaos de făina de cereale germinate, Rev. Chim., 2006, 56(5), 511-514.

5. TONK, S., MAJDIK, C., SZEP, R., SUCIU, M., RAPO, E., NAGY, B., NICULAE, A.G., Biosorption of $\mathrm{Cd}(\mathrm{II})$ ions from aqueous solution onto eggshell waste kinetic and equilibrium isotherm studies, Rev. Chim., 68(9), 2017, 1951-1958.

6. ION, V.A., PÂRVUlESCU, O.C., VELCEA, D., POPA, O., AHMADI, M., Physico-chemical parameters and antioxidant activity of Romanian sea buckthorn berries, Rev. Chim., 70(12), 2019, 4187-4192.

7. CIOROIU, D.R., PÂRVUlESCU, O.C., DOBRE, T., RADUCANU, C., KONCSAG, C.I., MOCANU, A., DUTEANU, N., Slow pyrolysis of Cystoseira barbata brown macroalgae, Rev. Chim., 69(3), 2018, 553-556.

8. HASSAN, T.A., RANGARI, V.K., RANA, R.K., JEELANI, S., Sonochemical effect on size reduction of $\mathrm{CaCO} 3$ nanoparticles derived from waste eggshell, Ultrason. Sonochem., 20, 2013, 13081315

9. MitTAL, A., TEOTIA, M., SONI, R.K., MiTTAL, J., Applications of egg shell and egg shell membrane as adsorbents: A review, J. Mol. Liq., 223, 2016, 376-387.

10.GURU, P.S., DASH, S., Sorption on eggshell waste - A review on ultrastructure, biomineralization and other applications, J. Mol. Liq., 209, 2014, 49-67.

11.BANU, C., IORDAN, M., NOUR, V., MUSTAȚĂ, G., Procesarea materiilor prime alimentare și pierderile de substanțe biologic active, Editura Tehnică UTM, Chișinău, 2003.

12.MENCINICOPSCHI, G., Și noi ce mai mâncăm? Coreus Publishing, 2010.

13.SALMAN, K.H., MANSOUR, A.I.A., TAMMAM, A.A., EL-GAZZAR, F.E., Utilization of eggshell powder as a calcium fortifier in stirred dibis probiotic yoghurt, Assiut J. of Agric. Sci., 43(1), 2012, 1-18.

14.HASSAN, M.N.M., Chicken eggshell powder as dietary calcium source in biscuits, World J. Dairy Food Sci., 10 (2), 2015, 199-206.

15.RAY, S., BARMAN, A.K., ROY, P. K., SINGH, B.K., Chicken eggshell powder as dietary calcium 
source in chocolate cakes, The Pharma Innovation Journal, 6(9), 2017, 1-4.

16.BRADAUSKIENE, V., MONTRIMAITE, K., MOSCENKOVA, E., Facilities of bread enrichment with calcium by using eggshell powder, $11^{\text {th }}$ Baltic Conference on Food Science and Technology. Food science and technology in a changing world, FOODBALT 2017, 91-95.

17.ALSUHAIBANI, A.A.M., Rheological and nutritional properties and sensory evaluation of bread fortified with natural sources of calcium, J. Food Quality, 2018, 1-7

18.ALI, M., BADAWY, W.Z., Utilization of eggshells by-product as a mineral source for fortification of bread strips, J. Food and Dairy Sci., 8(11), 2017, 455-459.

19.LEONTE, M., Tehnologii, utilaje, rețete și controlul calității în industria de panificație, patiserie, cofetărie, biscuiți și paste făinoase, Editura Ecozone, Iași, 2007

$\overline{\text { Manuscript received: } 10.06 .2020}$ 